\title{
The Gap Between Educational System and Job Market in International Business Law: A Model of Specialization for Solving the Problem
}

\author{
Seyedeh Armaghan Azhar ${ }^{1,}$, Mohammad Amin Zandi ${ }^{2}$ \\ ${ }^{1}$ Faculty of Law and Political Science, Allameh Tabataba'i University, Tehran, Iran \\ ${ }^{2}$ Mohammad Amin Zandi: Faculty of Economics, Allameh Tabataba'i University, Tehran, Iran \\ Email address: \\ armaghan.azhar@yahoo.com (S. A. Azhar), 9zandi@gmail.com (M. A. Zandi) \\ ${ }^{*}$ Corresponding author
}

\section{To cite this article:}

Seyedeh Armaghan Azhar, Mohammad Amin Zandi. The Gap Between Educational System and Job Market in International Business Law: A Model of Specialization for Solving the Problem. International Journal of Vocational Education and Training Research.

Vol. 3, No. 6, 2017, pp. 51-60. doi: 10.11648/j.ijvetr.20170306.11

Received: September 18, 2017; Accepted: October 25, 2017; Published: February 11, 2018

\begin{abstract}
One of the aims of higher education is obtaining advanced skills and specialty, and thereby offering better job opportunities after graduation. Examining the current educational system of Master level in Iran, we came to the conclusion that there is a lack of practice on necessary specialization in the domain of International Business Law. The train Master students receive is not directed towards their future profession, which leads to their being unable to have a good performance. In order to measure students' awareness of their academic and professional future and their attitude toward this major, a standard questionnaire was distributed to 34 female and male International Business Law students, admitted from 2009-2014. Since the students' attitude toward their job in the future showed they had a high expectation of their future occupation, and since the unemployment rate was reported to be $8.8 \%$, there is a concern about the prospective profession of the graduate students in this major. A profession-oriented model has been developed in an attempt to eradicate the problem. In this model, the students will be categorized as 8 different sub-majors after completion of the first general semester. The students' entrance to these sub-majors is a matter of interest and talent, which will be assessed by a panel of experts from International Business Law, Psychology, and Educational Consulting. These 8 groups are Lawyers, Arbitrators/Judges, Businesspeople, Legislators, Researchers, Negotiators, Legal Advisers, and Professors which offer possible job opportunities for the graduates. Then the teaching methodology in each sub-major is in accordance with the prospective employment.
\end{abstract}

Keywords: Teaching International Business Law, Job Oriented Teaching, Educational System, Job Market

\section{Current Educational System of International Business Law}

International Business Law in its simplest form is the regulation of the essential business practices of the world, which usually goes beyond the national states. Its main purpose is to provide a single legal framework to facilitate the worldwide trade. This international framework affect the costs of doing business positively so that they decrease considerably. Regional and International organizations serve this function by means of international conventions, multilateral and bilateral treaties, uniform customs and practices.

International Commercial Law is also an LLM degree in European and North American Universities and other parts of the world at the graduate level. ${ }^{1}$ At the university of Glasgow,

1 Some universities like Georgetown (U. S) offer this degree under the title "International Business \& Economics Law". Other universities like University of Glasgow (U. K) introduce this major under the name of "International Commercial Law." However, Palls Consortium offers LLM in European Business Law. (Wish, V. (2009, February 25). The LL. M. in Business Law / Commercial Law, Business Lawyers Want to Know: Is an LL. M. Worth the Time and Money. Retrieved December 16, 2015, from http://www.llm-guide.com/article/382/thellm-in-business-law-commercial-law). The choice of name at each school depends 
it is a 12-month full-time or 24-month part time degree. The structure of the program comprises lecture, seminar, group projects and presentations. Some of the reported courses at this university are Advanced competition law, corporate governance, E-commerce, international trade law, and international sales and finance. At this university, there is a compulsory one-week induction program, which is carried out in an attempt to elaborate on learning methods, research skills, and non-academic aspects of life and study in Glasgow.

Admission to the master level studies in Iran is granted to the undergraduate students through university entrance examination once a year. National Organization for Educational Testing (Sanjesh) $^{2}$ is responsible for administering a national test and announcing the results. Students will be assessed through a competitive multiple-choice examination bearing negative points if answered wrongly. The set of questions includes a variety of different subjects and the students who choose to be admitted in a specific major will answer the defined subjects mentioned in booklet number 1 of Sanjesh. The set of defined subjects for International Business Law examination includes Technical and General Language (either English or French), Civil law, Commercial Law, Public International Law, and Public Private International Law. In 2015, Sanjesh announced 94 places available for the examinees to International Business Law. This major has been established at the master level in Iran since 2009.

According to the statistics of Ministry of Science, Research and Technology (Iran), the acceptance to the master level of International Business Law started from 2005 and is provided for the examinees for the fall semester. From fall 2005 until fall 2013, the reported numbers of the students were 752. In addition, the alumni between 2008 until 2012 were $120 .^{3}$ In fall 2013, the entrants at Allameh Tabataba'i Univeristy were 100 students. The specific courses of this major at Allameh Tabata'i university for fall 2014 were : The Law of International Sale of Goods I \& II, Foreign Purchase, Law of Oil and Gas, International Commercial Arbitration, Law of Multinational Enterprises, International Commercial Insurances, World Trade Organization and its regulation, Law of International Carriage of Goods by Sea, Law of International Carriage of Goods by Air and Road, Conflicts of Law, International Contracts, E-Commerce Law, Law Texts, Seminar and Thesis. ${ }^{4}$

The courses follow almost the same methodology with only some differences. Throughout the courses, students become

on the coordinator's choice. The distinguishing element for global business law and international commercial law is the relation to macro-regulations or microregulations.

2 "Due to the increase in the number of applicants to higher education and expansion of universities, an advanced institution with a defined set of responsibilities in assessing students seemed necessary. As a result, establishment of National Organization for Educational Testing was ratified in 1976 and aimed at accepting best and most qualified students to the universities.

National Organization for Educational Testing. Retrieved May 29, 2016, from http://sanjesh.org/aboutus.aspx.

3 Ministry of Science, Research and Technology (Iran), Statistical Report on Number of Graduates and Entrees in International Business Law. Institute for Research \& Planning in Higher Education, 2015. Print.

4 Course Lists of Education Center, Allameh Tabataba'i University, Fall 2014. familiarized with the principles of international conventions, customs, treaties and other resources of this major. In addition, in some of the classes, students are required to present a lecture with presentation software, which comprises $20-30 \%$ of final grade. The final examination makes up $70 \%$ to $80 \%$ of final mark. The final exam resources are mainly class pamphlets, primary sources, and other articles relevant to the subject. ${ }^{5}$ However, no real-life experience, internship or practical courses are considered for these courses and students are encouraged to pursue professional experiences in other non-academic organizations.

Although acceptance into the master level of International Business Law in Iran is competitive ${ }^{6}$ and it has its popularity among students for its lucrative job market, the statistics show that $7 \%$ of total alumni in Iran including graduates and postgraduates are unemployed. In addition, Occupation Cooperative Organization of Academic Graduates reported the unemployment rate of Law to be $25.4 \%$. In a research in fall 2014, it was found that among 578'280 of Law graduates $315^{\prime} 734$ graduates were inactive and 52'138 unemployed. $^{7}$ In addition, according to the Trading Economics, the unemployment rate in Iran has increased up to $10.9 \%$ in the third quarter of $2015^{.8}$ As the current gap in the educational system and job market in International Business Law seems overwhelming, a review of current scholarship in educationjob seems inevitable.

\section{Literature Review}

Livingstone (1998) defines education-job gaps as "the discrepancy between our work-related knowledge and our opportunities to use this knowledge in an interesting and fairly compensated work." $\mathrm{He}$ asserts that underemployment is related to some dimensions like the talent use gaps, involuntarily reduced employment, the credential gap, and subjective underemployment. He then points out that although U. S employers find their employees to be proficient in technical skills, the gap between educational achievement and actual technical skills is still pervasive in North America. Fourie (2014) identifies a gap in work-readiness of university graduates, which is attributed to a deficiency in behavioral skills teaching on the part of the university in order to fulfill the expectations of internal audit practice.

In a study in U. A. E, significant implications for youth unemployment were recognized. It was stated that "the lack of

\footnotetext{
5 Students' Observations, September 2014-December 2015.

6 Their ranking and their grade among other participants assess students' acceptance. In fall 2010, the first admitted score was 9645, and the last admitted score was 4233, and 149 students were accepted among all the participants in Iran (Statistics of Ministry of Education and Ministry of Research, Science and Technology). For the first admitted grades visit: Interview with Rank 1 in International Business Law 2010. (n. d.). Retrieved December 18, 2015, from http://www.modaresanesharif.ac.ir/1428.

7 Educated at the University of Unemployment, which fields in the table are unemployed? / Annual migration of 180 thousand educated in Iran. (2015, June 22). Aftab Newspaper. Retrieved December 18, 2015, from http://aftabnews.ir/fa/news/303914.

8 Iran Unemployment Rate. (n. d.). Retrieved December 18, 2015, from http://www.tradingeconomics.com/iran/unemployment-rate.
} 
close links between the labor market and education sector decreases employability of many young Emiratis." 9 The result of this study showed that since the educational system does not provide necessary skills for the job market, curricula that are more professional should be incorporated into the system. However, $76 \%$ of the group study, which were young Emiratis, stated that higher education is a positive preparatory instruction for working environment. Vogel (2015) affirms this statement by mentioning, "Providing students with the tools and skills they will need to have to contest in the job market is considered to be one of the most effective. He considers strategic thinking, relevant experience of the workplace, and applied knowledge as those mandatory skills.

M. J. Atkins (2005) mentions some of the skills which both academic and employment domains have in common. He also puts emphasis on the role of higher education in bringing the public investment back to the society by its being capable of promoting employment-related skills. However, many academics in Iran do not consider universities responsible for training students so that they are able to enter the marketplace as professionals after graduation. ${ }^{10}$ Atkins then calls for an attention to the opinion that the rate of return to the economy might decrease gradually based on the current trend of the market. Underutilization of graduates will itself delay the return of invested money to the whole economy due to lack of employment-related skills of the graduates. Atkins defends his standing by saying that the gap in what university produces and what employers need is conspicuous. Employers find the graduates less than fully prepared for the responsibilities of a job and those who have been embedded in an employmentcentered environment have a better chance of adaptation to a professional position.

Perhaps one of the methods that business law instruction is utilizing for skill-development is through "case problem analysis". In most cases, "a case study method selects a small geographical area or a very limited number of individuals as the subjects of study. Case studies, in their true essence, explore and investigate contemporary real-life phenomenon through detailed contextual analysis of a limited number of events or conditions, and their relationships"11. A student of business law selects from the facts lying in the problem and takes the position of a manager to make decisions for settling the dispute. ${ }^{12}$ Satlow (1956) believes that the stages of making decisions for a legal case will create not only a discriminating sense but also the correct employment of legal principles. Although such abilities are necessary for a prospective lawyer, such abilities might not fit a would-be teacher or businessperson to be effective in his/her role.

\footnotetext{
9 Unemployed Youth in the UAE: Personal Perceptions, The International Council on Security and Development, February 2010, p 12.

10 This view is shared by the academics of the research location in which the students were studied which will be reflected in Scholars' viewpoints. (Allameh Tabatabat'i University, Spring 2015).

11 Zainal, Z. (2007). Case study as a research method. Jurnal Kemanusiaan, 9. Retrieved October 22, 2017.

12 An Approach to Case Analysis. (2006). Retrieved February 21, 2016, from http://plato.acadiau.ca/courses/Busi/IntroBus/CASEMETHOD.html.
}

In "A New Paradigm for The Teaching of Business Law and Legal Environment Classes" (2005), Lampe criticizes the legal approach, which exists in teaching business students. He asserts that business schools will not provide future lawyers or paralegals with business law undergraduate degree. He believes that as business law students will make business decisions, not legal decisions, pedagogical approaches for business law undergraduates should be more relevant to training prospective business practitioners.

Job prospects for International Business Graduates vary respectively. They range from a businessperson, lawyer, legal adviser, researcher, judge and dispute resolution specialist (and this might itself encompass arbitrator, mediator, adjucator, etc.), negotiator, and in higher levels, a university professor. The skills and demands for each of the groups mentioned above are not the same, as each field will focus on a specific domain, partly or very different from the others. Therefore, this article aims at assessing the current view of the LLM students and graduate students about their future job, and the possible profession they might get involved in. Later on, it will propose a change in the current educational system in International Business Law and suggest a model. Finally, it will report the views of some faculty members for a possible change and this model.

\section{Methodology}

In order to assess the status of unemployment in International Business Law in Iran, a mixed methods design including quantitative and qualitative methods was used in this study. In an attempt to assess students' perspectives toward their academic future, prospective profession, and the degree of awareness of their major, a standard questionnaire ${ }^{13}$ was distributed to males and females graduate students of class held between 2009 to 2014. Cochran's theorem was used to measure sample size. The respondents were selected from current international-business-law students and graduates of different universities from 2009 to 2014 . The population of the research was 762. According to Cochran's sample size formula, the sample size was 543 for each year with an error rate of 5\%. In order to find the necessary sample size and successfully filled questionnaires, 550 questionnaires were distributed based on simple random sampling method, and finally 543 questionnaires were analyzed.

Two sets of questions targeted at obtaining students' points of view on their major, post-graduation job prospects, and the compliance of the educational system with the need of labor market. The questions were based on Likert Scale. In order to measure scale reliability of the questionnaires, Cronbach's alpha was computed and it was found to be 0.842 which was quite acceptable. Therefore, the questionnaires were valid and reliable enough to be utilized for field research and statistical analysis.

Having ascertained that the questionnaires were valid and reliable, research hypotheses were formulated. Two statistical

13 Students' attitude of prospective career questionnaire, Hajian and Nasiri, 2005. 
hypotheses tests were used to assess the relationship between awareness of the students and their expectations, also for assessing the hypotheses of the research.

\section{Descriptive Analysis}

During the years of study, students' awareness of their major increases. However, their awareness of the compliance of educational system with job markets demands decreases considerably. This, itself, is a proof on the talent gap in International Business Law. The sets of hypotheses in this research were:

1. There is an inverse relationship between students' expectation of educational system for preparing them to the job market and their awareness of this major.
2. The students' awareness of their major is low.

The hypothesis test for this research was Kendall Rank Correlation Coefficient and Spearman's Rank Correlation Coefficient. For the second hypothesis, Chi-Square test was used. SPSS statistical analysis software was utilized to analyze the data. The results of tests for the first hypothesis showed that the students' expectations of the educational system for preparing them to job market decreases as their awareness of their major increases. The results of one-sample chi-square test for the second hypothesis showed that the students had little awareness of their major that is the proof for talent gap. Therefore, the hypothesis that there is no difference between the analyzed frequency and expected frequency was rejected. In the table below, the results of the tests are shown:

Table 1. Correlations between Expectation and Awareness.

\begin{tabular}{|c|c|c|c|c|}
\hline \multicolumn{5}{|l|}{ Correlations } \\
\hline & & & The students 'expectations & job market \\
\hline \multirow{6}{*}{ Kendall's tau_b } & \multirow{3}{*}{ The students' expectations } & Correlation Coefficient & 1.000 & -.020 \\
\hline & & Sig. (2-tailed) & & .514 \\
\hline & & $\mathrm{N}$ & 543 & 543 \\
\hline & \multirow{3}{*}{ job market } & Correlation Coefficient & -.020 & 1.000 \\
\hline & & Sig. (2-tailed) & .514 & . \\
\hline & & $\mathrm{N}$ & 543 & 543 \\
\hline \multirow{5}{*}{ Spearman's rho } & \multirow[t]{3}{*}{ the students' expectations } & Sig. (2-tailed) & . & .524 \\
\hline & & $\mathrm{N}$ & 543 & 543 \\
\hline & & Correlation Coefficient & -.027 & 1.000 \\
\hline & \multirow[t]{2}{*}{ job market } & Sig. (2-tailed) & .524 & . \\
\hline & & $\mathrm{N}$ & 543 & 543 \\
\hline
\end{tabular}

In Figure 1, the comparison is demonstrated:

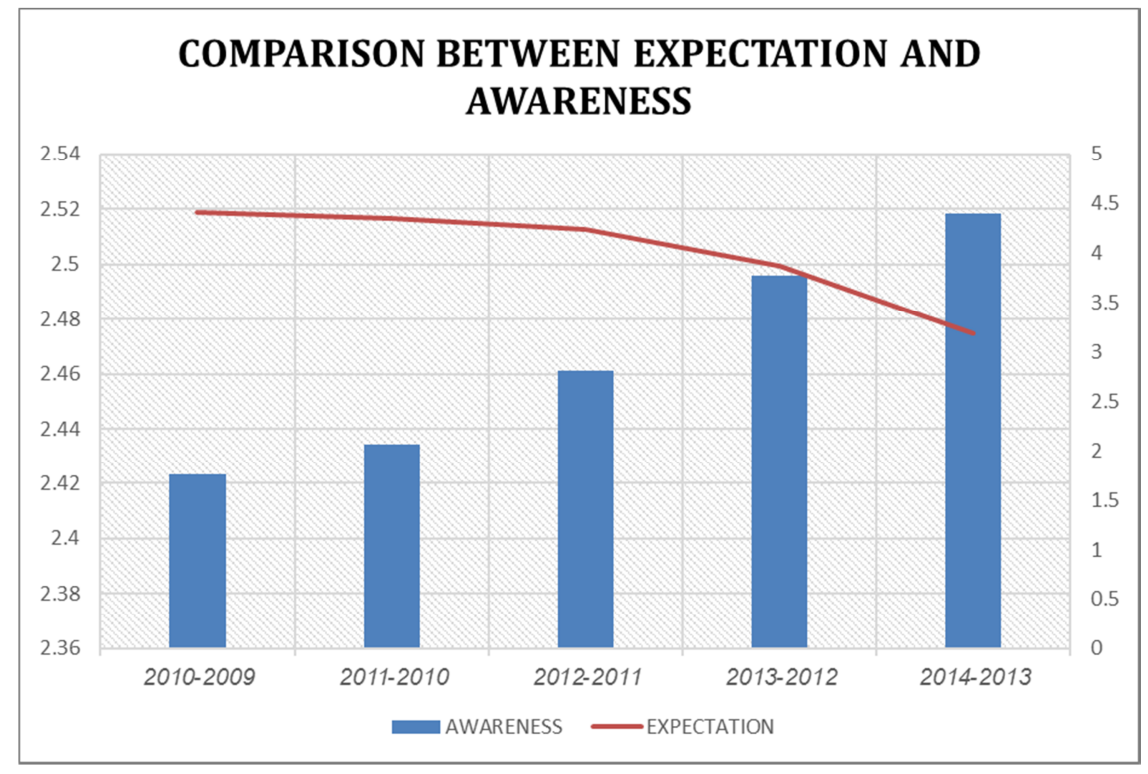

Figure 1. Comparison Between Expectatioon And Awareness.

\section{The Model for Improving the Current Educational System}

\subsection{Proposed Model}

Based on what statistics show about the rate of unemployment and according to the students' high expectation of their prospective profession after graduation, the current academic instruction in International Business Law is not meeting students' objectives. Studies show that this gap is attributed largely to the perspective that the academic instruction is not profession-based. However, 
according to the statistics, through this method the students may excel in the theoretical realm, but they cannot employ their knowledge in practical fields like lawyering, arbitration, business, banking etc. The proof for this claim is the fact that the graduates' skills do not meet the employers' expectations in many cases. Accordingly, many students have to seek relevant training courses outside the academic atmosphere. That is why, perhaps, the Azad News Agency announced in statistics in 2013 that $14 \%$ of the graduates settle in unrelated careers of their majors for continuing their lives. ${ }^{14}$

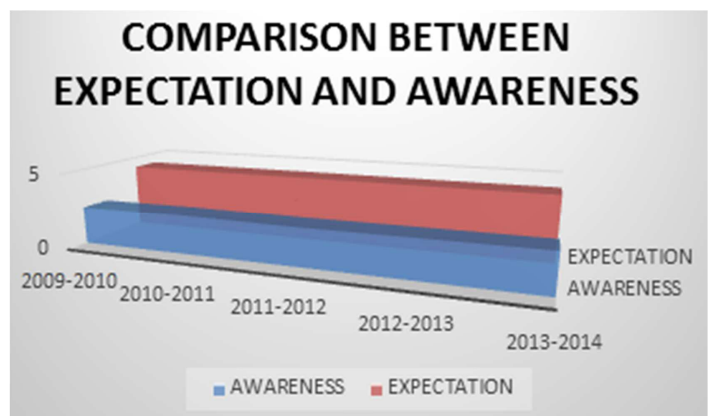

Figure 2. Comparison between Expectation and Awareness.

In order to graft the academic practice with the need of the job market and to make the educational system more responsive, a new model of graduate study is proposed. The logic behind this model is that since each profession requires certain skills, the teaching methodology can be separated as well. It must be added that this new system can get along with other practices like online programs, training courses, or different LLMs. Undoubtedly, for the introduced groups, further advanced courses or higher educations can be presented, thus leading into educating and training more professionals. Grasping the necessity of this separation, the objective of the universities in this major should be reviewed.

Many universities offering International Business Law have proposed the career prospects of the alumni. The University of Leeds elaborates on career opportunities as:

"This programme will help enhance your career prospects not only in terms of the legal profession but in any career where analysis, initiative, problem solving and an understanding of legal concepts and rules within the business environment are desirable". ${ }^{15}$

As LLM of international business law can meet many objectives and create different job opportunities after graduation, it seems necessary for this major to have an outlook toward future graduate professions in order to design its curricula and academic programs. According to this new model, International Business Law provides students with one general semester in order to be acquainted with the rudiments of this major. However, for the second semester, the approach will be different.

14 A. (2015, April 22). University and Employment, two separate roads. Retrieved April 03, 2016, from http://www.ana.ir/news/24259.

15 LM International Business Law-Career Opportunities. (n.d.). Retrieved April 12, 2016, from http://www.law.leeds.ac.uk/postgraduates/taughtpostgraduates/llm-international-business-law.
Although career prospects vary in this major ${ }^{16}$, they can be narrowed down into certain specific groups in consistence with the responsibilities and personality character that each category (i.e. the future profession of International Business Law) demands. It must be emphasized that although some of the skills in each class might overlap, this division leads to more precision; hence, there will be less wastage of time over unnecessary materials. Due to this classification, students will choose to continue in one of these classes based on their personality type, talents, and interest ${ }^{17}$. As a result, students will be trained according to the objectives and requirements of the class, which is in fact in parallel with a greater aim i.e. future profession. This will avoid any concern and uncertainty about career prospects.

The entrance of students into the second semester is mainly based on two criteria: talent and interest. In addition, as each group requires certain skills ${ }^{18}$ and talents, the students are carefully assessed in order to be qualified for one of the groups. This selection will be evaluated by a panel of experts composed of an Educational Consultant, a Psychologist, and a faculty member of International Business Law. This panel will examine each student's CV, the results of Talent and Interest tests $^{19}$, and student's tendencies. Later on, the panel of experts will hold an interview with each student. The outcome is a leading factor for the entrance of the students into the second semester. Thereby, each student will continue what she/he is interested in and motivated about based on the knowledge he/she has gained in the first semester.

One of the advantages that this scrutinizing will bring

16 Career prospects: "Students who successfully completed the International Business Law (IBL) Master's programme have a wide range of career choices. They can work as professional business lawyers, in-house legal counsels for companies, government officials, corporate executives, legal professionals for an international (intergovernmental) organization, etc. Our alumni have jobs at, for example, international law firms, banks and international accounting companies in their home countries or in the Netherlands. Others pursue a career as a legal counsel in government institutions or international organizations. A number of students choose to further develop their academic skills by enrolling into a $\mathrm{PhD}$ programme at VU University Amsterdam or elsewhere. (International Business Law (LLM). (n. d.). Retrieved April 12, 2016, from https:/www.vu.nl/en/programmes/international-masters/programmes/gi/international-business-law-LLM/career-prospects/index.aspx).

17 Tests of talents are now quite known in psychology; e.g., DATs (Differential Aptitude Test) assesses different skills like verbal reasoning, numerical ability, logical reasoning, and other aptitudes. For more information, see: www.belvederecollege.ie/.../APTITUDE-TEST-EXPLANATION. For 16personality type, the panel can also get the help of The Myers-Briggs Type Indicator which is a questionnaire to assess the psychological preferences of people and which categorized people into 16 different personality type and proposes suitable professions for each type. For more information, please see: The Myers \& Briggs Foundation - MBTI ${ }^{\circledR}$ Basics. Retrieved April 16, 2016, from http://www.myersbriggs.org/my-mbti-personality-type/mbti-basics/ .

18 Although one might consider the discussed skills of the groups in this article overlapping, it must be mentioned that there is a core skill for each group that the focus and target of the group teaching must be aligned with that. An example is about researchers that "curiosity development" is a core skill for them.

19 Some of these tests are named as Wechsler Adult Intelligence Scale (WAIS), Revised NEO Personality Inventory (NEO PI-R), Jung Typology Test, Myers \& Briggs Foundations, The Watson Glaser critical thinking test, The Wagner Preference Inventory, Personal Thinking Style, Torrance Tests of Creative Thinking, Strong Interest Inventory, and etc. 
about is the self-cognition that results in wise choices. If any student recognizes that he/she does not have enough interest in and talent for the specific professions in the second semester, he/she can drop out of this major with less opportunity cost. In this case, much will be saved for the students and the academics both.

The possible groups introduced here are based on what the current job possibilities of International Business Law are. Obviously, the groups can be extended if the curricula, skills, and instruction are introduced consequently. For every single group, the skills, materials, assessments, and even the instructor's skill will be different which will be discussed
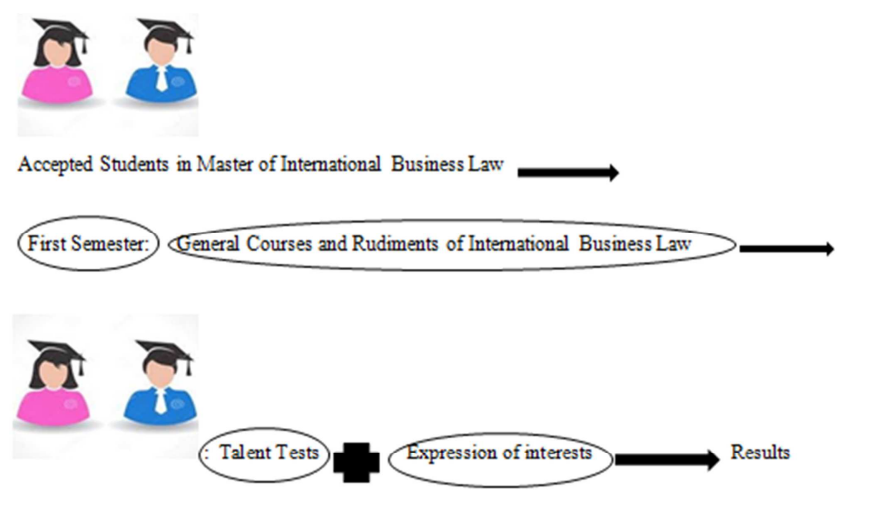

(tii!

: Analyzing the Results $\longrightarrow$

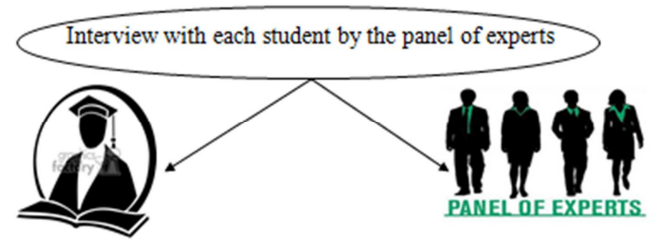

$\longrightarrow$ Entrance of the student into one of the groups

Figure 3. Propsed Model Flowchart.

Lawyers: The practice of law consists of taking advantage of certain rules, principles, logics and applying them for defending a case before a court or performing a legal demand of a client. Hence, an LLM student who is sitting in "lawyers' class" must achieve the required skills for excelling himself/herself with a legal case. $\mathrm{He} / \mathrm{She}$ is not required to outperform a serious legal research or to write a dissertation. Rather, he/she must be familiar with legal writing, data collection, and logical reasoning, analytical ability, attention to details, and persuasiveness. ${ }^{20}$ Thus, in this model, a legal atmosphere will surround him/her where all the practices,

20 Furlong, J. (2008, July 04). Core competence: 6 new skills now required of lawyers - Law21. Retrieved April 07, 2016, from

http://www.law21.ca/2008/07/core-competence-6-new-skills-now-required-oflawyers later on. The division, in fact, leads to a more specialized LLM program and therefore the better preparation of the graduates. The above-mentioned groups are Lawyers, Business people, Judges/Arbitrators, Researchers, Negotiators, Legal Advisers, Legislators, and University Professors. Hence, students will continue their education of LLM into one of these groups according to the talent test results, their own interest, and the evaluation of the panel of experts. This division will also avoid unrequired training or examinations. Skills and curricula in each of the groups are discussed subsequently, which is another proof for this division. An overview of the assessment is shown below: curricula, assessment, and the backgrounds of faculties are law practicing i.e. lowering. The students will be exposed to complicated cases in order to enhance their decision-making power and defend a case before a court. An LLM graduate of the class of "Lawyers" is fully prepared to continue practicing law according to previous experiences. Above that, the instruction in a class of "international business lawyers" can be set toward training the lawyers who practice law among the nations, among the states, or among individuals on an international scale.

Another proof of this training is the ruling of the Supreme Court of Canada in Central Trust Co. v. Rafuse, [1986] 2 SCR 147, 1986 CanLII 29 (SCC) in which it insists that a solicitor does not need to know all the applicable law:

"A solicitor is required to bring reasonable care, skill and knowledge to the performance of the professional service which he has undertaken. The requirement of professional competence that was particularly involved in this case was reasonable knowledge of the applicable or relevant law. A solicitor is not required to know all the law applicable to the performance of a particular legal service but he must have a sufficient knowledge of the fundamental issues or principles of law applicable to the particular work he has undertaken to enable him to perceive the need to ascertain the law on relevant points."

Businesspeople: The world of business as challenging and risk-taking as it is, demands entrepreneurial characteristics. As some International Business Law students may find themselves more adaptable with the business world, they may choose to abandon passing the bar exam, and be involved in Business domain. The class of "Business people" will align with all the practices (including assessment, materials, and methodology of teaching) toward training professionals in the world of commerce, trade, business, and entrepreneurship. The must-have qualities of every single entrepreneur are taught and emphasized crucially in this class. Some of these characteristics are industriousness, cooperativeness, initiation and decision-making power, impressive personality, discipline, courage, leadership and honesty. For a student of International Business Law with the preference of "business", developing such skills will not be too challenging to become internalized as she/he has been trained under the guidance of professors who specialize in business.

Judges/Arbitrators: Dispute resolution has different forms 
and each practice is associated with the relevant nature of a legal case. ${ }^{21}$ For a student of International Business Law entering the second semester in a class of Judge/Arbitrator, developing logical reasoning and common sense is of utmost necessity. Commitment to impartiality, commitment to the judicial profession, commitment to justice and sensitivity toward people concerning legal order. Such characteristics of a good judge have not changed significantly in two millennia. Therefore, as the first semester, the required talents and interest separate students, we might expect that this group of students get directed toward legal reasoning and judicial wisdom by the practice of the class. Would-be judges/arbitrators in International Business Law can gain an insight into the way they should rule over a legal case in the commercial world.

Researchers: an undeniable quality for any student seeking to become a researcher is the enthusiasm for discovering things; sifting the information; pursing an aim, being able to propose solutions to a problem. Of course, such a competency can be found in the students who are curious enough to ask many questions in the first semester and to seek their answers passionately. Having such a competency can prepare an International Student for higher degrees in $\mathrm{Ph}$. D. or SJD as well. ${ }^{22}$

Toledo-Pereyra (2012) mentions 10 qualities of a good researcher; naming "interest, motivation, inquisitiveness, commitment, sacrifice, excellence, knowledge, recognition, scholarly approach, and integration", these skills can be well acquired for a would-be researcher, since the panel has previously been found out to be a well talented and motivated researcher.

Negotiators: Once it has been determined that a student can be effective in negotiation domain and possess the talent and orientation toward mastering a negotiation round, he/she can sit in Negotiation class. The type of traits that are going to be inculcated in a negotiator is a willingness to tolerate disagreement and confrontation, persistence and a refusal to surrender in the face of opposition, thinking clearly under

21 Dispute resolution encompasses some different forms among which arbitration is perhaps the most popular one. It is similar with litigation in a way that requires an impartial party to render a decision. However, it is distinguished with traditional court proceedings in a way that it is voluntary, controlled, private, informal, adjudicative, binding/non-binding, confidential, adversarial, and flexible. Due to many advantages of arbitration, it might be preferable for many cases especially in commercial disputes. It is suggested that even the class of arbitrators can be another groups as the nature of it is different from that of a litigation. For more information, see: Dispute Resolution Reference Guide. (2016, March 18). Retrieved April 10, 2016, from http://www.justice.gc.ca/eng/rp-pr/csjsjc/dprs-sprd/res/drrg-mrrc/06.html

22 Doctor of Juridical Science, Doctor of the Science of Law, (in Latin) Scientiae Juridicae Doctor or Juridicae Scientiae Doctor (sometimes also referred to as a Doctor of Laws), abbreviated S. J. D. or J. S. D., respectively, is a research doctorate in law and doctorate equivalent to the $\mathrm{Ph}$. D. It is offered primarily in the United States, where it originated, in Canada and in Australia. As a research doctorate, it follows professional training in law (LL. B. or J. D.) and the first graduate-level training in law (Master of Laws), and is primarily aimed at educating professors, legal scientists, and other scholars in law. For more information, visit: S. J. D. (n. d.). Retrieved April 19, 2016, from https://en.wikipedia.org/wiki/S.J.D. stress, stamina, indifference to a failed negotiation. ${ }^{23}$ Hence, in a class of negotiators, quick thinking, and creativity in the face of opposition are emphasized in order to educate best negotiators. As a negotiator requires a great knowledge of international commercial regulations, he/she will be taught in a class of accomplished negotiators who will not only provide the necessary knowledge, but will help the students to attend international internship for grasping a real-world practice.

Legal Advisers: National Career Service defines job profile of a court legal adviser in England and Wales as "Court legal advisers (sometimes known as court clerks) in England and Wales are able to represent the Justices' Clerk, and advise magistrates and District Judges"24. Legal advisers are employed by large corporations, the government and other organizations to provide legal advice and services to the public as a whole rather than an employer. Legal advisers are called upon after a legal dispute has occurred or before signing a contract or corporate decisions. ${ }^{25}$

As this position also requires certain personal qualities, the panel of experts can recognize these qualities in a student for directing him/her into the second semester. These characteristics are named as awareness of social issues, maturity, interpersonal abilities like understanding people's feelings, problem-solving, decision-makings, awareness of the importance of confidentiality and reliability ${ }^{26}$ Although some of these skills might have some commonalities with other groups, the core of the skills for this group is the ability to comprehend people's feeling and altruistic traits. Therefore, the teaching methodology for this group will be oriented toward developing this skill.

Legislators: Although constituents elect lawmakers, their characteristics to some extent will affect the kinds of policies. Indeed, other factors like constituent pressures, party leaders, interest groups and institutional rules can deviate their decisions, but their backgrounds will play a role in their points of view ${ }^{27}$. Donald Matthews (1954) mentions in his book that: "the social and psychological characteristics of the individual officials acting within a political institutional framework must be considered before an adequate understanding of politics and government is possible." 28 Therefore, it seems mandatory for the expert panel to take the

23 Potgeier, J. (n. d.). Negotiations Training Skills. Retrieved April 23, 2016, from http://negotiationsworkshop.com/negotiation-training-Negotiation-SeminarSecrets-The-5-Key-Characteristics-of-Successful-Negotiators.html.

24 See more at

https://nationalcareersservice.direct.gov.uk/advice/planning/jobprofiles/Pages/cou rtlegaladviser.aspx\#sthash.BeRX5Dm7.dpuf.

25 Legal Advisor: Job Description and Education Requirements. (n. d.). Retrieved April 25, 2016, from

http://study.com/articles/Legal_Advisor_Job_Description_and_Education_Requir ements.html

26 Magistrates Court Legal Advisor. (2009). Growing Ambitions. Retrieved April 26, 2016, from https://growingambitions.tes.co.uk/printpdf/2659.

27 Carnes, N., \& Lauderdale, B. E. (2011, March 22). Legislator Characteristics, Constituency Characteristics and Roll Call Voting. Retrieved April 29, 2016, from http://benjaminlauderdale.net/downloads/CarnesLauderdale2011MPSA.pdf 28 Matthews, D. R. (1954). The social background of political decision-makers. Garden City, NY: Doubleday. 
personal characteristics, background, interest, and previous experiences of the students in order to assess his/her qualification not only for entering the class of Lawmakers but also in the society.

Due to this demanding position and pressure outside, the techniques which have been taught and knowledge of the political system and principles of law encoding might heavily influence a "lawmaker", culture, literature, and the effects of any changes in commercial law on citizen's life must be regulated toward educating the most competent legislators ${ }^{29}$. Philosophers and politicians have also stressed out other skills. ${ }^{30}$ The nucleus skill can be assertiveness and word keeping in this class. As this class is going to be instructed by lawmakers themselves, the practical experiences can be well granted to the student.

University professors: In these groups, it is considered that the prospective university professors will play a central role in directing the students, as they should be able to direct the next generation students in the most effective way. As a result, showing enthusiasm for teaching and having high grades $^{31}$ can be a leading factor for the expert panel and the students themselves to enter the class of university professor in the second semester. Other personality types like interest in people, value for other people's feelings, structure, and organization, harmony, organizational capabilities, the need for approval from others can be taken into consideration. ${ }^{32}$ It is assumed that knowledge and enthusiasm are core characters for a would-be university professor. Therefore, for the educational part of the class, the curriculum will be designed from methodology suitable for teaching business law.

\subsection{Scholars' Viewpoints}

An interview was done with four faculty members of Allameh Tabata'i University to reflect upon the educational system and the newly proposed model. All of the faculty members mentioned that there is a gap between higher education in university and job market. However, they mentioned that the university is mainly responsible for teaching theories in an academic domain rather than training professionals. They all mentioned that the syllabi demonstrate practical aspects in the first look, though the teaching methodology is not practical. Two of the faculty members mentioned that the gap is mainly due to the obligatory educational plans by the ministry of science and education and due to lack of cooperation between universities

29 For more information, please visit: Owens, J. E., Schraufnagel, S., \& Li, Q. (2016). Assessing the Effects of Personal Characteristics and Context on U. S. House Speakers Leadership Styles, 1789-2006. SAGE Open, 6 (2). doi:10.1177/2158244016643143.

30 Benjamin Franklin: "Honesty is the best policy".

31 Sandalow, T. (n. d.). On Becoming a Law Professor. Michigan Journal of Race \& Law, 582. Retrieved May 1, 2016.

32 In Myers-Briggs Test, the types of personality suitable for a profession of a university professor are ENFJ, ESFJ, INFJ, and ISTJ. For more information, please visit: Snyder, D. (2011). Do You Have the Personality for Teaching? Presented at the 2011 Illinois Music Educators Association All-State Conference in Peoria, Illinois. and job market. Therefore, students must seek professional training courses outside the university. One of the professors mentioned that this lack of skills would pose problems in the effectiveness of the graduates applying for the job market. They stated that they try to make their teaching practical. One of them noted that he tries to dedicate $70 \%$ of the class to theories and $30 \%$ to real-life practices. One of the faculties expressed that as he himself is a lawyer he adds everyday experiences into the class atmosphere.

One of the faculties stated that there is no need to change the educational system of International Business Law. However, three others believed that the syllabi and teaching methodology should be designed in a way that they align well with the job market. The possible professions that a graduate of International Business Law can choose were the groups introduced in this article. One of the faculties totally disagreed with any change and movement toward professionalism. Another faculty welcomed professionalism but pointed out the lack of resources and considered the students responsible for passing training courses. One another faculty member affirmed that cooperation between university and job market is a necessity, but considered a change in syllabi to be sufficient. Finally, a faculty member said that not only the university should disregard teaching unnecessary materials, but also it should concentrate on educating students in one specific field, which is on a par with their future career.

\section{Conclusion}

The current educational system of International Business Law, which is mainly based on teaching theories, does not cater well for the need of job market. Therefore, graduate students of International Business Law will not be effective in the workplace. In addition, the empirical studies showed that the students do not choose this major with former knowledge about it. This leads to a gap between students' future career and the major they have chosen. The rate of unemployment is another matter which affirms this claim about the ineffectiveness of the teaching methodology of this major. Since the students expect to have great job opportunities after graduation, it seems necessary that the current educational system in this major undergo a change. The proposed model for meeting the students' needs is mainly based on two criteria that are talent and interest. In this model, the students who choose International Business Law pass one semester in order to become familiarized with the rudiments of this major. For the second semester, the students take the talent exams. In addition, an interview is held between each student and a panel of experts. The panel of experts consists of an expert in educational consulting, psychology and international business law itself. Based on the results of the tests, and the interview the students sit in different classes that are based on future profession. The classes are for future lawyers, university professors, negotiators, judges/arbitrators, legal advisers, business people, and researcher. The classes can extend if there are other job 
opportunities discovered for this major. This model ascertains that each student sits in the class that is based on his/her talents and interests.

Although some of the scholars still hesitate about the efficacy of this model, this model can be examined in a real university experience and the results can be a leading factor for deciding about the future of International Business Law.

\section{Appendices}

-Regarding the theme of this paper: Perhaps one of the most related quotations describing this article is the famous quote by Plato: 1 Each man is capable of doing one thing well. If he attempts several, he will fail to achieve distinction in any.

-The questions on Students' attitude of prospective career questionnaire, Hajian and Nasiri, 2005 that was based on Likert scale:

Future Academic Awareness:

1. I was personally interested in my major before I enter it.

2. My interests changed after I entered the university.

3. My attitude toward the major changed more positively in comparison with the first year.

4. I started my education in my favorite field in order to succeed.

5. I was aware of my major before National Examination to university.

6. I encouraged others to choose this major.

7. If I were to re-take the National Examination to University, I would choose this major again.

8. There is an encouraging motivating educational system in this major.

9. I have enough theoretical knowledge for studying this major.

10. I have enough practical knowledge to study this major.

11. The teaching system of this major is suitable.

12. The faculties of this major are up to date.

13. The faculties have good personal traits.

14. The number of faculties are sufficient.

15. I have talent in my major.

16. I have interest in my major.

17. There are good research fields in this major.

18. The incomprehensible parts of the courses resolve through studying more.

19. The problems of this major can be solved with the help of the university administration.

20. This major will give me good social status.

21. I have financial problem for continuing this major.

22. There is a proper health advice system for the students of this major.

23. It is possible for the students to continue education in this major.

24. I do not think about dropping out of college.

25. I feel confident about studying this major.

26. The current problems do not affect my interest toward this major.

Prospective Profession Awareness:
27. I am aware of my prospective profession.

28. I am aware of the required skills of my future job.

29. I am optimistic about my future occupation.

30. The job of my major is interesting and purposeful.

31. My attitude toward my prospective profession has not changed since my entry to the university.

32. My attitude toward my prospective profession has changed positively.

33. There is proper education for the success of my future job.

34. There is good job market for my major.

35. The society thinks positively about my future occupation.

36. My prospective profession will have a good social status.

37.I will have better job opportunities through continuing my education.

38. I will not be less interested if I think about working in the deprived areas.

39. There are good opportunities for helping people and providing services to them in my future job.

40. There is good opportunity for being in touch with people in my future occupation.

41.I can be internally satisfied through my future job.

42. I will have job security in my profession.

43. I will have social security in my profession.

44. I can acquire the social status I want in my future job.

45. My future profession will have positive affect on the society.

46. My future profession will have positive affect on the society's health.

47. I will be financially secure in my future profession.

48. There is the possibility of high income in my future job.

49. I will not need to have another job to make ends meet.

50.I will have regular working hours in my prospective profession.

51. My future profession will have high professional responsibilities.

52. My future profession is not demanding.

53. My future job is independent.

54. The chance of being employed is high in my society.

55. There is a good consulting system in my university.

56. My future profession does not have many challenges.

57. I can utilize my personal skills in my future occupation.

58. My future profession requires manual abilities.

59. My future profession requires mental abilities.

60. My future profession is based on great knowledge.

61 . The problems of my future profession will be resolved with having proficiency.

-Three question which were not on Likert Scale:

1. Do you work now? Please specify.

2. If you do not work, please mention the profession you would like to choose.

3. Is your current / future profession related to your major?

The set of questions for interview were:

a. Is there a problem concerning the lack of practical training in the educational system of International 


\section{Business Law in Iran?}

b. How much does the educational system of International Business Law in Iran align its syllabus and teaching methodology with job market?

c. How much does your teaching methodology (faculty member) prepare students for entering the job market?

d. Do you (faculty member) consider any change in educational system necessary? In addition, if yes how should this change be oriented?

e. What prospective jobs can a graduate of International Business Law expect?

f. Do you (faculty member) agree with professionalizing International Business Law based on prospective jobs?

g. Do you (faculty member) agree with the proposed model of this article?

\section{References}

[1] Al Azri, S. (2010). Unemployed Youth in the UAE: Personal Perceptions (pp. 11, 12). DIANE Publishing.

[2] Atkins, M. J. (1999). Oven-ready and Self-basting: Taking stock of employabilityskills. Teaching in Higher Education, 4 (2), 267-280. Retrieved February 15, 2016.

[3] Data of Institute for Research and Planning in Higher Education, WWW.IRPHE.IR WWW.IRPHE.AC.IR (2014, September 15). Increase of Unemployed Graduates in Unemployment of the Country. IR Economy. Retrieved December 18, 2015, from http://www.ireconomy.ir/fa/page/15352.

[4] David Satlow, Handling Cases in the Law Class, Business Education Forum, XI, November, 1956.

[5] Fourie, H. (2015). Work-readiness of university graduates: An internal audit educational expectation gap in South Africa (Doctoral dissertation, UNIVERSITY OF PRETORIA, 2014) (p. 18). Ann Arbor, MI: ProQuest LLC.

[6] Lampe, M. (2005, December 12). A NEW PARADIGM FOR THE TEACHING OF BUSINESS LAW AND LEGAL Retrieved March 04, 2016, from http://onlinelibrary.wiley.com/doi/10.1111/j.08965811.2005.00020.x/abstract Central Trust Co. v. Rafuse, [1986] 2 SCR 147, 1986 CanLII 29 (SCC),

$<\mathrm{http}: / /$ canlii.ca/t/1 ftsl $>$, retrieved on 2016-04-19

[7] Livingstone, D. W. (1998). The education-jobs gap: Underemployment or economic democracy. Boulder, CO: Westview Press.

[8] Manual selection entrance exam graduate degree (MS) in 1394. (2015, May 10). Retrieved October 11, 2015, from http://www6.sanjesh.org/download/arshad94book/1Ensani.pdf.

[9] Manual postgraduate entrance examination (postgraduate courses inside) 1394. (2014, November 8). Retrieved October 10, 2015, from http://www.sanjesh.org/group.aspx?gid=2.

[10] Nayler, P. (2006). Business law in the global marketplace: The effects on international business. Oxford, Eng.: Elsevier Butterworth-Heinemann.

[11] Nelson, J. W. (1989). What Makes a Good Judge? Journal of the National Association of Administrative Law Judiciary, 9 (2), 153-154. Retrieved April 23, 2016.

[12] Pourkazem. (2014, October 8). The Most and Least Opportunities of Job among Academic Majors. Retrieved December 18, 2015, from http://www.bargharshad.ir.

[13] Seth, S. (2016, February 5). 10 Characteristics of Successful Entrepreneurs | Investopedia. Retrieved April 08, 2016, from http://www.investopedia.com/articles/personal finance/101014/10-characteristics-successfulentrepreneurs.asp

[14] Toledo-Pereyra, L. H. (2012). Ten Qualities of a Good Researcher. Journal of Investigative 17- Surgery, 25 (4), 201202. doi:10.3109/08941939.2012.701543.

[15] University of Glasgow. (n. d.). Retrieved December 16, 2015, from http://www.gla.ac.uk/postgraduate/taught/international commercial law/.

[16] Vogel, P. (2015). Generation jobless? Turning the youth unemployment crisis into opportunity (p. 105). Palgrave Macmillan UK.

[17] Zainal, Z. (2007). Case study as a research method. Jurnal Kemanusiaan, 9. Retrieved October 22, 2017. 